\title{
Price Behaviour \\ Of New Share Listings In Nigeria
}

Olatunde Otaniyi, University of South Africa, South Africa

Daniel Makina, University of South Africa, South Africa

\begin{abstract}
The paper investigates whether new listings on the Nigerian Stock Exchange are under-priced or not. On aggregate, we find that investors are able to make abnormal gains from new listings on the first tier (main) market of the Nigerian Stock Exchange (NSE). Our analyses show that up to one year after listing the average differences of real share prices are positively significant to confirm the observation. The situation is however different in the second (emerging) tier market. Our analyses show that the real prices of newly listed shares in the second tier market do fall. Such an observation could, however, be attributed to thin trading of shares which phenomenon is characteristic of second tier markets. When we partition the data into pre-and post-deregulation periods, we observe under-pricing of new equity listings to have been severe during the prederegulation period, and hence more opportunity for abnormal gains. We find opportunities for making abnormal gains to be not as strong during the post-deregulation period. When the data is analysed on the basis of whether or not new listings are financial institution firms, some interesting patterns of price behaviour are found. While we observe possibilities of making abnormal gains in new listings of non-financial companies and insurance companies, these possibilities are absent in new listings of banking sector shares indicating that they are efficiently priced relative to those of other sectors.
\end{abstract}

Keywords: Nigerian Stock Exchange; new share listings; under-pricing; abnormal gains; EMH; deregulation

\section{INTRODUCTION}

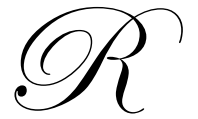

esearch interest in pricing of new issues of shares has concentrated more on under-pricing in an effort to determine whether or not investors can take advantage of such phenomenon (Furst, 1970; Van Horne, 1970; Allen and Faulhaber, 1989). Empirical work has concentrated in advanced capital markets like New York Stock Exchange (NYSE) and American Stock Exchange (AMEX). It has been found that though under-pricing seems to exist with the possibility of significantly large returns for initial subscribers within the first week or month of listing of the new issue or listing, rapid adjustment of prices to available information often lead to subsequent returns after the initial first week or month not being significantly different from normal (McDonald and Fisher, 1972). This behaviour is consistent with the Efficient Market Hypothesis (EMH). Some studies on efficiency of the capital market in Nigeria have found the market to be inefficient in the weak form (Nwanbiankea, 1990) and also in the semi-strong form (Olowe, 1996). No studies in Nigeria have been done to examine market efficiency from the angle of examining price behaviour of new listings and this paper is an endeavour to fill this research gap.

Since stock exchange activities have often been seen as leading indicator and vehicle for economic growth and development, this has informed Nigerian government policies aimed at facilitating and encouraging privately held companies to go public. It is significant that these policies have yielded desired results of increasing the number of equity listings on the emerging Nigerian Stock Exchange (NSE) set up in 1960. As at the end of 2008, listed securities were 301 and listed companies stood at over 200 on the Nigerian Stock Exchange. Market capitalization in 2008 was US $\$ 80.6$ billion compared with US $\$ 105.65$ billion in 2007 , a decline precipitated by the global crisis. Prior to 1993, the pricing of new equity listings in Nigeria was done by the then Capital Issues Commission that later metamorphosed into the Securities and Exchange Commission (SEC). After deregulation in 1993, issuing 
houses in collaboration with corporate managers took over the function of pricing new equity listings. However, during both the pre-and post-deregulation periods, various complaints and objections had been raised regarding pricing of new equity issues vis-à-vis the prices on the secondary market determined by market forces. Odife (1993, p.31) for instance noted that "securities prices in Nigeria are unduly depressed. It has been shown that a wide discrepancy exists between the prices fixed by the SEC and those prevailing on the stock exchange".

This paper investigates the price of behaviour of new share listings to determine the possibility of abnormal gains at the Nigerian Stock Exchange (NSE) which is an emerging market. Data was collected for new listings that took place from 1989 to 2004 in the first tier (main) and second tier (emerging) markets of the exchange. Since the Nigeria Stock Exchange was deregulated in 1993, it was also possible to analyse price behaviour of new listings during both the pre- and the post-deregulation periods. The main finding of the paper is that investors are able to make abnormal gains from new listings on the first tier (main) market. This finding is in contrast with those observed in developed markets where new listings do not provide opportunities for investors to make abnormal gains.

The rest of this paper is structured as follows. Section 2 gives a brief discussion of the relevant literature on issues involved. Section 3 describes the research method of and data sources. Section 4 presents analyses of the data and interpretation of the results. Finally, section 5 concludes.

\section{LITERATURE REVIEW}

When many companies whose shares were previously traded on the over-the-counter (OTC) market sought and got approval for listing on the big exchanges in the United States of America in the earlier part of the 1960s, market watchers and researchers picked up interest in the phenomenon of pricing of new issues. There was interest to examine the reasons for the companies' action with a view to analyse the benefits that accrue to the companies and the investors. Van Horne (1970) observed that a total of 456 companies' shares were newly listed on the NYSE between 1960 and 1967. He also gave the number of new listings on the AMEX between 1962 and 1967 as 481 .

The benefits of listing on the big stock exchanges were enumerated by Furst (1970) to include increase in the market price of the newly listed common stocks due to improved marketability and prestige, and the free publicity that the company enjoys. These benefits are advanced to be the main reason that investors respond favourably to the listing of a new stock. The proposition is that, It is proposed that after the announcement to list a stock rises in price relative to the market and should continue to do so when first traded on an exchange. Thereafter, the price levels off. The supposition by Merjos (1967) is that this latter behaviour is due to profit taking by traders who bought the stock prior to listing in expectation of an upward move in price.

If the above described pattern of stock-price behaviour is significant, there exists in the market an opportunity for gain. Accordingly, market participants would purchase a share upon announcement of listing (or upon listing in the context of absence of an over-the-counter market as in the case of some emerging markets like the Nigerian market) and later sell it off when the price has risen. Such an investment strategy would allow the participants take advantage of the increase in value that presumably accompanies a decision to list. Should the price pattern become systematic, participants would be assured of a gain. However, the action by a number of market participants engaged in this kind of activity should drive out the opportunity for gain through arbitrage as information filters through. In other words, if the market adjusts very quickly as proposed by the Efficient Market Hypothesis (EMH), the described pattern of stock prices for new listings is without economic foundation and seemingly should not exist (Fama, 1965).

The Efficient Market Hypothesis (EMH) evolved from the Random Walk Theory and the Fair Game Model in which researchers like Kendall (1953, pp. 11-25) found that " in a series of prices which are observed at fairly close intervals, the random changes from one term to the next are so large as to swamp any systematic effect which may be present. The data behave like wandering series." Fama $(1965,1970)$ later developed the EMH classifying efficient capital markets into three types: weak form, semi-strong form, and strong form efficiency. 
The weak form of the EMH claims that prices fully reflect the information implicit in the sequence of past prices. The semi-strong form of the hypothesis asserts that prices reflect all relevant information that is publicly available, while the strong form of market efficiency asserts that information that is known to any participant is reflected in market prices.

The EMH consequently involves defining an efficient market as one in which trading on available information fails to provide an abnormal profit. A market can be deemed to be efficient therefore, only if we posit a model for returns. Hence, tests of market efficiency became joint tests of market behaviour and models of asset pricing.

Empirical tests conducted to verify the various forms of efficiency of the capital market have found capital markets in advanced countries to be efficient in the weak form (Fama, 1970, 1991) and in the semi-strong form (Fama et al., 1969). There have been other studies with contrary results to these findings (see for example, Basu, 1977; Poterba and Summers, 1988). Roll (1994) observes that it is remarkably hard to profit from even the most extreme violations of market efficiency and hence labelling stock market anomalies as chance events that do not persist into the future.

Most empirical studies on the efficiency of the capital markets in emerging markets are centred on testing the weak form efficiency and findings are mixed. While it is generally believed that the emerging markets are less efficient, empirical evidence does not always support this belief. For instance, Branes (1986), Chan et al. (1992) and Ojah and Karemera (1999) found weak-form efficiency on the Kualar Lumpur market, major Asian markets and the four Latin American countries' stock exchanges respectively. On the other hand, Cheung et al. (1993), Mobarek and Keasey (2000) found that the Korean, Taiwan and Dhaka, Bangladesh stock exchanges were not efficient in the weak-form sense. In a World Bank study, Claessens et al. (1995) report significant serial correlation in equity returns from 19 emerging markets and suggest that stock prices in emerging markets violates the weak-form EMH. Similar findings are reported by Harvey (1994) for most emerging markets.

With regard to emerging markets in Africa, Dickinson and Muragu (1994), Osei (1998), Matome (1998), Roux and Gilbertson (1978) came to the same conclusion of lack of weak form efficiency on the Nairobi, Ghana, Namibia and Johannesburg Stock Exchanges respectively. Empirical studies by Ayadi (1984) and Samuel and Yacout (1981) on the NSE found the market to be weak form efficient. This was however refuted by Ekechi (1989) and Nwanbiankea (1990). Few attempts have been made to test the semi-strong efficiency hypothesis of the NSE. Olowe (1996) using stock splits concluded that the Nigerian capital market was not semi-strong efficient. Oludoyi (1997) cited by Adelegan, (2004) did a study on the impact of earnings announcements on share prices in Nigeria. He showed that the Nigerian capital market is not efficient in the semi-strong form as share prices still drift ten weeks after corporate earnings have become public information.

Various reasons have been advanced for the findings of non-efficiency in the weak and strong form in emerging markets. Khababa (1998) did a study of Saudi Arabian financial market which he found to be inefficient in the weak form and opined that the inefficiency might be due to delay in operations and high transaction costs, thinness of trading and liquidity in the market. Akpan (1995) gave similar rationale on the inefficiency of the Nigerian Stock Exchange, that is, attributing it to the relative thinness of the market.

In the presence of strong evidence of inefficiency in price determination, expectations are high of the possibility of high returns by traders and investors when right steps are taken in buying and selling newly listed shares or new issues of already listed companies on an emerging stock exchange. Possibilities of making abnormal gains through new listings on the Nigerian Stock Exchange have motivated this paper. It is to be noted also that prior empirical work reviewed dwelt mainly on the general efficiency of the capital market from the viewpoint of the EMH and drew conclusions on the implication of their findings on the general price behaviour of prices of shares. To our knowledge, no specific study has been done on the price behaviour of new listings or new equity issues in the Nigerian capital market and this paper is an attempt to fill this research gap. 


\section{RESEARCH METHODOLOGY}

\subsection{Source and Description of Data}

The data used for the research is the quoted price of newly listed shares on the Nigerian Stock Exchange from 1989 to 2004. The quoted price for each new listing was obtained for the following dates:

(i) Listing date

(ii) One month after listing

(iii) Two months after listing

(iv) Three months after listing

(v) Six months after listing

(vi) One year after listing.

The empirical investigation undertaken involved analysis of prices of newly listed stocks over these six dates. The quoted prices were obtained from the Daily Official List (DOL) of the Nigerian Stock Exchange. The DOL provides daily trading information for all securities listed on the Stock Exchange - first tier (main) and second tier (emerging) markets. The new listings whose share prices were obtained for various dates comprised 75 first tier companies and 20 second tier companies.

The day on which a company's shares newly going public was first listed on the stock exchange would normally fall on a normal week day (Monday to Friday) on which trading took place on the floor of the Exchange. Trading would not take place on the stock if subsequent dates like one month after listing or two months after listing etc. fell on a weekend (Saturday or Sunday) or on a public holiday. In such a case, price on the nearest date (to the exact date) in which trading took place was used. If for example the exact date for a month after listing fell on a Saturday, the price for the previous day (Friday) was used. If it fell on a Sunday, the price on the next day (Monday) was used. This goes also for exact dates for one month after listing, two months after listing etc. that fell on a public holiday. Adjustments were made in the prices of shares that were indicated as having gone ex-dividend on any of the dates for which data were captured for a particular share. The dividend amount was added back to the quoted price to reflect the true value of such shares on that particular day.

\subsection{Data Analysis Techniques}

The method of analysis was adopted from Van Horne (1970) with some modifications. The modification made was the basis of comparison of the changes in the price level between two dates. Van Horne applied Standard and Poor's industry averages which he indexed. Stock prices for various dates before, on and after listing were also indexed. The industry average index was then subtracted from the indexed price of the newly listed stock to arrive at the change in price for the listing stock from the base date, holding constant the effect of industry stock-price movements. In this paper, share (stock) prices for various dates were deflated by the Consumer Price Index (CPI) to arrive at real share prices for the various dates. We used monthly CPI obtained from the International Monetary Fund (IMF) for Nigeria for the various dates. It is to be noted that the IMF CPI series for Nigeria has January 1978 as its base date while this study is on new shares listings on the Nigerian Stock Exchange from August 1989. The nominal share prices were deflated using the technique described by Spiegel (1972). This deflation technique involved forming new CPI series with August 1989 as the base month. Each quoted price for the various dates were then divided by the corresponding index number to obtain the real quoted price. As in Van Horne (1970) transactions costs were considered not critical to the outcome of our analyses. Van Horne found no significant average differences when transactions costs were taken into consideration.

We proceeded to do comparisons between real stock prices on a base date and real stock prices on a forward date to arrive at the differences between them over time. Using Van Horne's (1970) technique, these differences for all shares are summed and averages computed which were then used in the evaluation of price movements of new listings over the chosen six dates. The significance of the average differences was then tested by means of a t-test using the statistical method of paired comparison as explained in Battacharyya and Johnson (1977). The t-ratios for paired combinations of dates were calculated using the equation: 
$t=\frac{\sum D / n}{S_{D}}$

where $\mathrm{D}$ is the difference between the real quoted price of the share on a forward date and the real price of that share on a base date, $\mathrm{n}$ is the total number of observations and $\mathrm{S}_{\mathrm{D}}=$ the standard error about the average $\mathrm{D}$. The computed ratios were tested as to whether changes in the real market price of newly listed shares between each of the six dates were significant. The listing date, three months after listing and six months after listing were used as base dates in our analyses. This implied that for each subset of analysis the paired comparison done were between:

(i) Listing date to one month after listing;

(ii) Listing date to two months after;

(iii) Listing date to three months after;

(iv) Listing date to six months after;

(v) Listing date to one year after;

(vi) Three months after listing to six months after;

(vii) Three months after listing to one year after; and

(viii) Six months after listing to one year after.

\section{ANALYSES AND DISCUSSION OF RESULTS}

The average differences between the real prices for the stocks in the sample for the first tier market are shown in Table 1.

Table 1: Average Differences for First tier Market New Listings, 1989-2004 (75 0bservations)

\begin{tabular}{|l|l|c|c|}
\hline & Average Difference & t-Ratio \\
\hline 1. & Listing Date (LD) to 1 month after & 3.39 & $2.98^{*}$ \\
\hline 2. & Listing Date (LD) to 2 months after & 5.66 & $2.50^{*}$ \\
\hline 3. & Listing Date (LD) to 3 months after & 5.89 & $2.96^{*}$ \\
\hline 4. & Listing Date (LD) to 6 months after & 7.48 & $2.67 *$ \\
\hline 5. & Listing Date (LD) to 1 year after & 9.25 & $2.09 *$ \\
\hline 6. & 3 months after listing to 6 months after & 1.59 & 1.08 \\
\hline 7. & 3 months after listing to 1 year after & 3.37 & 0.84 \\
\hline 8. & 6 months after listing to 1 year after & 1.77 & 0.51 \\
\hline$*$ Significant at 5 \% level & & \\
\hline
\end{tabular}

The results in Table 1 are consistent with the postulated pattern of stock prices rising upon new listing of shares. The average real price of listing stock rises after the listing date up to one year after listing. The t-ratios are significant at 95 percent confidence level for average differences between listing date (LD) and one month after listing; LD and two months after; LD and three months after; LD and six months after; and LD and one year after. The fact that the average differences between the listing date and one year after are significant is consistent with listing enhancing the value of newly listed shares. Given this information there would appear to be an opportunity for gain to market participants who buy stocks upon the announcement to list or immediately after listing and sell them within one year after listing. However, the average differences in real prices between three months after listing and six months after listing; three months after listing to one year after; and six months after listing to one year after are not significant.

The results are different in the second tier market as shown in Table 2. Only the average difference in real stock prices between listing date to 3 months after listing is positively significant at $5 \%$ level. All other average differences with respect to listing date are not significant at 5\% level. The average differences between listing date and one year after is negative, and so is between three and six months after; three months and one year after; and between six months and one year after listing. The average difference between three months after listing and one year after and between six months after listing and one year after are significant at 5\% level. This shows that the real prices at the second tier market actually falls six months after the listing date. 
Table 2: Second tier market new listings, 1989 - 2004 ( 20 0bservations)

\begin{tabular}{|c|c|c|c|}
\hline & & Average Difference & t-Ratio \\
\hline 1. & LD to 1 month after & 2.31 & 1.37 \\
\hline 2. & LD to 2 months after & 3.51 & 1.61 \\
\hline 3. & LD to 3 months after & 4.91 & $1.85 *$ \\
\hline 4. & LD to 6 months after & 3.66 & 1.34 \\
\hline 5. & LD to 1 year after & -0.29 & -0.10 \\
\hline 6. & 3 months after to 6 months after listing & -1.24 & -1.24 \\
\hline 7. & 3 months after to 1 year after listing & -5.20 & $-2.44 *$ \\
\hline 8. & 6 months after to 1 year after listing & -3.96 & $-2.56^{*}$ \\
\hline
\end{tabular}

The result obtained for the second tier (emerging) market of the NSE is definitely informed by the fact that the listing requirements on the second tier market are less stringent than those on the first tier market. Besides, shares of the companies on the second tier market are less actively traded compared with those on the first tier market. We also have fewer companies newly listed on the second tier market (20) as compared with those newly listed on the first tier market (75) for the period of our study.

It stands to reason from the results obtained with respect to the first tier market of the NSE to assert to some extent that there is evidence of inefficiency. The fact that average differences in real prices after listing are positively significant confirms opportunity for abnormal gains by prudent and discerning investors at the NSE. The evidence also supports the hypothesis that on the average listing enhances the value of the shares. Enhancement in this sense relates to the ability to buy a share at one date and sell it at another and to realize a measurable significant profit from the transaction. The fact of under pricing of new equity listings is also supported by the evidence on an aggregate basis on the first tier segment of the NSE.

Under pricing of new listings was further explored according to listings before or after deregulation of the capital market in Nigeria. Deregulation of the market came into force in the first quarter of 1993. All new share listings at the first tier market up to end of first quarter of 1993 (30 firms) were separated from those listed after March $31^{\text {st, }} 1993$ (45 firms). Results of the analyses of average differences for the pre-deregulation new listings are shown in Table 3. The average differences in real stock prices between listing date and one month later, two months later, three months later and six months later are significant at 5\% level. All the other average differences analyses are not significant.

Table 3: First tier market pre-deregulation new listings, 1989-1993 (30 0bservations)

\begin{tabular}{|l|l|c|c|}
\hline & & Average Difference & t-Ratio \\
\hline 1. & Listing Date (LD) to 1 month after & 5.31 & $2.53^{*}$ \\
\hline 2. & Listing Date (LD) to 2 months after & 9.30 & $1.85^{*}$ \\
\hline 3. & Listing Date (LD) to 3 months after & 8.65 & $2.11^{*}$ \\
\hline 4. & Listing Date (LD) to 6 months after & 13.24 & $2.39^{*}$ \\
\hline 5. & Listing Date (LD) to 1 year after & 12.30 & 1.62 \\
\hline 6. & 3 months after listing to 6 months after & 4.59 & 1.61 \\
\hline 7. & 3 months after listing to 1 year after & 3.64 & 0.58 \\
\hline 8. & 6 months after listing to 1 year after & -0.95 & -0.23 \\
\hline$*$ Significant at 5 \% level & & \\
\hline
\end{tabular}

This result is a proof of the observation that share prices that were determined by government regulatory agencies for new listings were unduly depressed as compared to the price that prevail in the secondary market for shares. The rationale for this assertion is further buttressed by the results for the post-deregulation new share listings displayed in Table 4. The table shows that only the t-ratios for average differences between listing date and two months after and between listing date to three months after listing are significant at 5\% level. All other average differences are found not to be significant. This shows that after deregulation quoted prices of new listings are arrived at by prudent consideration of market factors that ensure optimality in the pricing. 
Table 4: First tier market post-deregulation new listings, 1993-2004 (45 0bservations)

\begin{tabular}{|l|l|c|c|}
\hline & \multicolumn{1}{|c|}{ Average Difference } & t-Ratio \\
\hline 1. & Listing Date (LD) to 1 month after & 2.10 & 1.67 \\
\hline 2. & Listing Date (LD) to 2 months after & 3.24 & $1.88^{*}$ \\
\hline 3. & Listing Date (LD) to 3 months after & 4.04 & $2.16^{*}$ \\
\hline 4. & Listing Date (LD) to 6 months after & 3.64 & 1.30 \\
\hline 5. & Listing Date (LD) to 1 year after & 7.22 & 1.33 \\
\hline 6. & 3 months after listing to 6 months after & -0.40 & -0.27 \\
\hline 7. & 3 months after listing to 1 year after & 3.18 & -0.61 \\
\hline 8. & 6 months after listing to 1 year after & 3.58 & 0.70 \\
\hline$*$ Significant at 5 \% level & & \\
\hline
\end{tabular}

Cognisant of the dominance of financial institutions on the Nigerian Stock Exchange, new share listings further analysed with companies partitioned as financial institutions and non-financial institutions.. The Nigerian economy has been found to exhibit the bank dominated economy syndrome (Adebiyi, 2005). The listed financial institutions companies are mainly banks and insurance companies. The data used in this paper contains forty-three (43) financial institution companies and thirty-two (32) non-financial institution companies whose shares were newly listed during the period under consideration.

Table 5 shows the average differences in real stock prices for the financial institutions. Only the t-ratio for average differences between LD and one month after, LD and three months after, and the LD and six months after listing are significant. All others are not significant. Contrast these results with the average differences and t-ratios for the non-financial institutions companies in Table 6 which has significant t-ratios at 5\% level from listing date up to one year after.

Table 5: Financial Institutions First tier market new listings, 1989 - 2004. (43 0bservations)

\begin{tabular}{|l|l|c|c|}
\hline & & Average Difference & t-Ratio \\
\hline 1. & Listing Date (LD) to 1 month after & 3.35 & $2.29^{*}$ \\
\hline 2. & Listing Date (LD) to 2 months after & 5.46 & 1.69 \\
\hline 3. & Listing Date (LD) to 3 months after & 5.07 & $2.85^{*}$ \\
\hline 4. & Listing Date (LD) to 6 months after & 4.26 & $1.77^{*}$ \\
\hline 5. & Listing Date (LD) to 1 year after & 6.27 & 1.13 \\
\hline 6. & 3 months after listing to 6 months after & -0.81 & -0.59 \\
\hline 7. & 3 months after listing to 1 year after & 1.21 & 0.22 \\
\hline 8. & 6 months after listing to 1 year after & 2.01 & 0.37 \\
\hline$*$ Significant at 5 \% level & & \\
\hline
\end{tabular}

The results for non-financial institutions are along the pattern observed for the overall market (see Table 7). The fact that average differences up to six months from listing date has significant t-ratio for the financial institutions as compared with up to one year for the non-financial institution equities may be giving some signal of the efficiency pattern on the Nigerian Stock Exchange. We could deduce that the financial institution sector of the market could be more efficient than the non-financial institution sector.

Table 6: Non-Financial Institutions First tier market new listings, 1989 - 2004 (32 0bservations)

\begin{tabular}{|l|l|c|c|}
\hline & & Average Difference & t-Ratio \\
\hline 1. & Listing Date (LD) to 1 month after & 3.43 & $1.89^{*}$ \\
\hline 2. & Listing Date (LD) to 2 months after & 5.94 & $1.90^{*}$ \\
\hline 3. & Listing Date (LD) to 3 months after & 6.99 & $1.73^{*}$ \\
\hline 4. & Listing Date (LD) to 6 months after & 11.82 & $2.07^{*}$ \\
\hline 5. & Listing Date (LD) to 1 year after & 13.25 & $1.83^{*}$ \\
\hline 6. & 3 months after listing to 6 months after & 4.82 & 1.68 \\
\hline 7. & 3 months after listing to 1 year after & 6.26 & 1.06 \\
\hline 8. & 6 months after listing to 1 year after & 1.44 & 0.38 \\
\hline$*$ Significant at 5 \% level & & \\
\hline
\end{tabular}


Further insights are obtained through partitioning of the financial sector new share listings into separation newly listed banks and newly listed insurance companies. Out of the 43 financial institution companies in the data, twenty-four (24) are banks while the remaining nineteen (19) are insurance companies. Table 9 shows the average differences for the newly listed banks share prices while Table 9 shows the analysis for the insurance companies.

Table 7: Banking Institutions First tier market new listings, 1989 - 2004 (24 0bservations)

\begin{tabular}{|l|l|c|c|}
\hline & \multicolumn{1}{|c|}{ Average Difference } & t-Ratio \\
\hline 1. & Listing Date (LD) to 1 month after & 1.99 & 0.92 \\
\hline 2. & Listing Date (LD) to 2 months after & 2.02 & 0.86 \\
\hline 3. & Listing Date (LD) to 3 months after & 1.87 & 1.26 \\
\hline 4. & Listing Date (LD) to 6 months after & -1.29 & -1.06 \\
\hline 5. & Listing Date (LD) to 1 year after & -4.62 & -1.45 \\
\hline 6. & 3 months after lasing to 6 months after & -3.16 & $-1.77 *$ \\
\hline 7. & 3 months after listing to 1 year after & -6.49 & -1.71 \\
\hline 8. & 6 months after listing to 1 year after & -3.33 & -1.19 \\
\hline$*$ Significant at 5 \% level & & \\
\hline
\end{tabular}

It is notable that the first three out of the eight average differences points for banks are positive while the remaining five are negative showing a fall in average real prices over time after listing. Only the average difference between 3 months to 6 months after listing is significant, albeit in the negative direction. In contrast to the banking sector new listings the insurance companies new share listings average differences are all positive except for the six month after to one year after listing period. For the insurance companies t-ratios are significant at the 5\% level for listing date to one month after; listing date to three months after; listing date to six months after and listing date to one year after showing that investors could possibly make abnormal gains from new share listings in real terms up to one year after. The pattern is the same a observed for the overall market.

Table 8: Insurance Companies First tier market new listings, 1989 - 2004 (19 0bservations)

\begin{tabular}{|l|l|c|c|}
\hline & \multicolumn{1}{|c|}{ Table 8: Insurance Companies First tier market new listings, 1989- 2004 (19 0bservations) } \\
\hline 1. & Listing Date (LD) to 1 month after & Average Difference & $2.67^{*}$ \\
\hline 2. & Listing Date (LD) to 2 months after & 5.04 & 1.45 \\
\hline 3. & Listing Date (LD) to 3 months after & 9.66 & $2.61^{*}$ \\
\hline 4. & Listing Date (LD) to 6 months after & 8.95 & $2.39^{*}$ \\
\hline 5. & Listing Date (LD) to 1 year after & 11.42 & $1.88^{*}$ \\
\hline 6. & 3 months after listing to 6 months after & 10.93 & 1.31 \\
\hline 7. & 3 months after listing to 1 year after & 2.47 & 0.43 \\
\hline 8. & 6 months after listing to 1 year after & 1.98 & -0.12 \\
\hline$*$ Significant at 5 \% level & -0.49 & \\
\hline
\end{tabular}

The results show the banking sector's newly listed shares to be efficiently priced hence there is no room for abnormal gains. Based on this price behaviour the banking sector could be considered to be efficiently priced relative to other sectors of the Nigeria Stock Exchange. In fact, as Table 10 illustrates bank shares are more actively traded as compared with other sectors. This leaves little or no avenue for making abnormal profit from newly listed bank shares as compared with other sectors.

Table 9: Turnover Volume of 20 Most Actively Traded Stocks (No. of shares in Millions)

\begin{tabular}{|c|c|c|c|c|c|c|c|c|c|c|}
\hline & \multicolumn{2}{|c|}{2002} & \multicolumn{2}{|c|}{2003} & \multicolumn{2}{|c|}{2004} & \multicolumn{2}{|c|}{2005} & \multicolumn{2}{|c|}{2006} \\
\hline & $\begin{array}{c}\text { No of } \\
\text { Shares } \\
\text { Traded }\end{array}$ & $\%$ & $\begin{array}{c}\text { No of } \\
\text { shares } \\
\text { Traded }\end{array}$ & $\%$ & $\begin{array}{c}\text { No of } \\
\text { shares } \\
\text { Traded } \\
\end{array}$ & $\%$ & $\begin{array}{c}\text { No of } \\
\text { Shares } \\
\text { Traded }\end{array}$ & $\%$ & $\begin{array}{c}\text { No of } \\
\text { Shares } \\
\text { Traded }\end{array}$ & $\%$ \\
\hline Banks & 3499.1 & 79.1 & 8271.1 & 85.0 & 10493.5 & 91.1 & 16444.9 & 90.0 & 26198.88 & 90.3 \\
\hline Others & 922.6 & 20.9 & 1462.3 & 15.0 & 1027.0 & 8.9 & 1836.2 & 10.0 & 2823.75 & 9.7 \\
\hline Total & 4428.5 & 100.0 & 9733.5 & 100.0 & 11520.5 & 100.0 & 18281.1 & 100.0 & 29022.63 & 100.0 \\
\hline
\end{tabular}

Source: Computed From Nigerian Stock Exchange Facts Book 2003 to 2007 


\section{CONCLUDING REMARKS}

On aggregate, we find that investors are able to make abnormal gains from new listings on the first tier (main) market of the emerging Nigerian Stock Exchange (NSE) something that is not possible in advanced markets like the NYSE and AMEX. Our analyses show that up to one year after listing the average differences of real share prices are positively significant to confirm the observation. The situation is however different in the second tier market of the NSE where the real prices of newly listed shares actually decline over time.

When we partition the data into pre-and post-deregulation periods, we observe under-pricing of new equity listings to have been severe and hence more opportunity for abnormal gains during the pre-deregulation period. We find opportunities for making abnormal gains to be not as strong during the post-deregulation period. When the data is analysed on the basis of whether or not new listings are financial institution firms, some interesting patterns of price behaviour are found. While we observe possibilities of making abnormal gains in new listings of non-financial companies and insurance companies, these possibilities are absent in new listings of banking sector shares. We find the banking sector exhibiting more market efficiency relative to other sectors of the Nigerian Stock Exchange. Overall, our findings suggest that there are indeed possibilities of getting high returns from new equity listings in an emerging market as they are likely to be under-priced on initial listing. The price behaviour of new equity listings reflect lack of pricing efficiency.

\section{REFERENCES}

1. Adebiyi, M.A., 2005. Capital Market Performance and the Nigerian Economic Growth In: Fakiyesi, O.O. \& Akano, O. (eds.) Issues in Money, Finance and Economic Management in Nigeria.

2. Adelegan, O. J., 2004. How efficient is the Nigerian Stock Market: Further evidence. African Review of Finance and Banking, pp. 145-165.

3. Akpan, O.E., 1995. Thin and Thick Capital Markets: Empirical Test of Evidence for the Nigerian Stock Exchange. Nigerian Journal of Economic and Social Studies, 37(1) pp. 75-85

4. Allen, F. \& Faulhaber, G.R., 1989. Signalling by under pricing in the IPO Market. Journal of Financial Economics, 23, pp. 303-323.

5. Ayadi, F.O., 1984. The Random Walk Hypothesis and the Behaviour of Share Prices in Nigeria. The Nigerian Journal of Economic and Social Studies, 26(1), March, pp. 57-71.

6. Basu, S., 1977. The Investment Performance of Common Stocks in Relation to their Price to Earnings Ratio: A Test of the Efficient Markets Hypothesis. Journal of Finance, 32, pp. 663-682.

7. Battacharyya, G.K. \& Johnson, R. A., 1977. Statistical Concepts and Methods. New York: John Wiley \& Sons.

8. Branes, P., 1986. Thin trading and stock market efficiency: A case of the Kuala Lumpur Stock Exchange. Journal of Business Finance \& Accounting, 13(4) winter, pp. 609-617.

9. Chan, K. C. Gup, B. E. \& Pan, M., 1992. An empirical Analysis of Stock Prices in Major Asian Markets and United States. The financial Review, vol-27, no-2, May, pp-289-307.

10. Cheung, Y. Wong, K; \& Ho, Y., 1993. The Pricing of Risky Assets in two Emerging Asian markets Korea and Taiwan. Applied Financial Economics, 3(4), December, pp.315-324.

11. Claessens, S. Dasgupta, S. \& Glen, J., 1995. Return behaviour in emerging Stock Markets. The World Bank Economic Review, 9(1), pp. 131-151.

12. Dickinson, J.P. \& Muragu, K., 1994, Market Efficiency in Developing Countries: A case study of the Nairobi Stock Exchange. Journal of Business Finance \& Accounting, 21(1), January, pp. 133-150.

13. Dimson, E. \& Mussavian, M., 1998. A Brief History of Market Efficiency. European Financial Management, 4(1), March, pp. 91-103.

14. Ekechi, A.O.,1989. Weak-form efficiency in the Nigerian Stock Exchange. African Review of Money Finance and Banking, 1, pp. 5-16.

15. Ekiran, O., 2002. Nigerian Securities and Exchange Commission: Two Decades of Operation. Lagos: Intervention Finance Company Ltd.

16. Fama, E., 1965. The Behaviour of Stock Market Prices. Journal of Business, 38. pp. 34-105.

17. Fama, E.,1970. Efficient Capital Markets: A review of theory and Empirical Work. Journal of Finance, 25(2) May, pp. 383-417. 
18. Fama, E., 1991. Efficient Capital Markets II. Journal of Finance, 46, pp. 1575-617.

19. Fama, E. Fisher, L. Jensen, M. \& Roll, R., 1969. The adjustment of stock Prices to new information. International Economic Review, 10, pp. 1-21.

20. Feldman, R.A. and M.S. Kumar 1995 Emerging Equity Markets: Growth, Benefits, and Policy Concern. The World Bank Research Observer, 10( 2) August, pp. 181-200,

21. Furst, R. W., 1970. Does Listing Increase the Market Price of Common Stocks? Journal of Business, 43, pp. 174-180.

22. Harvey, C. R., 1994.Conditional Asset Allocation in Emerging markets. Working paper No 4623, Cambridge M.A.

23. Kendall, M., 1953. The Analysis of Economic time Series. Journal of the Royal Statistical Society, Series A, 96, pp. 11-25.

24. Khababa, N., 1998, Behaviour of stock prices in the Saudi Arabian Financial Market: Empirical research findings. Journal of Financial Management \& Analysis, 11(1), Jan-June, pp. 48-55.

25. Matome, T.K., 1998. Price Discovery Process of the Namibian Stock Exchange and the Informational content of the Share Index. Savings and Development, 22(3), pp. 283- 301.

26. McDonald, J.G. \& Fisher, A.K.,1972. New issue stock Price Behaviour. Journal of Finance, 27, pp. 97102.

27. Merjos, A., 1967. Up on the Curb. Barron, (May 1, 1967).

28. Merjos, A., 1967. Going on the Big Board. Barron, (May 29, 1967).

29. Mobarek, A. and Keasey, K. 2000., Weak-form Efficiency of An Emerging Market: Evidence from Dhaka Stock Market of Bangladesh. A paper presented at the ENBS Conference, Oslo, May, 2000.

30. The Nigerian Stock Exchange. 1989-2004. Daily Official List. Lagos: The Nigerian Stock Exchange.

31. The Nigerian Stock Exchange. 1990-2005. Fact Book. Lagos: The Nigerian Stock Exchange.

32. Nwabiankea, C.A.P., 1990. Testing the Efficiency of the Stock Market Using the Random Walk Hypothesis: A case Study of the Nigerian Stock Market. M.Sc. Dissertation. University of Lagos.

33. Odife, D., 1993. The Nigerian Securities Market. Lagos: Malthouse Press Ltd.

34. Ojah, K., \& Karemera, 1999. Random walks and Market efficiency Tests of Latin American Emerging Equity Markets: A Revisit. The Financial Review, 34, pp. 57-72.

35. Okereke-Onyiuke, N., 2004. Significance of Capital Market in Economic Development: The Global Trends. A paper delivered at the Nigerian Stock Exchange Biennial Conference for CEOs and directors of quoted companies.

36. Olowe, R.A., 1996. Semi-Strong Information Efficiency of the Nigerian Stock Market: Evidence from Stock Splits. Ph.D. thesis, University of Lagos.

37. Oludoyi, S.B., 1997: Capital Market Efficiency and the Effects of Earnings Announcements on Share Prices in Nigeria. Unpublished Ph.D. Thesis, University of Ibadan, Nigeria.

38. Osei, K.A., 1998. Analysis of Factors affecting the Development of an Emerging Capital Market: A Case of the Ghana Stock Market. African Economic Research Consortium Research paper 76.

39. Osinubi, T.S., 1998. Stock Market Development and Long-run Growth in Nigeria. M.Sc. University of Ibadan, Nigeria.

40. Poterba, J. \& Summers, L.,1988. Mean reversion in Stock Prices: Evidence and implications. Journal of Financial Economics, 22, pp. 27-59.

41. Roll, R., 1994. What Every CEO Should Know About Scientific Progress in Economics: What is Known and What Remains to be Resolved, Financial Management, 23, pp. 69-75.

42. Roux, F.J.P. \& Gilbertson, B.P., 1978. The behaviour of share prices on the Johannesburg Stock Exchange. Journal of Business Finance and Accounting, 5 (2), pp. 223-232.

43. Samuels, J.M. \& Yacout, N., 1981. Stock Exchanges in Developing Countries. Savings and development. 5(4), pp. 217-230.

44. Spiegel, M. R., 1972. Theory and Problems of Statistics. New York: Schaum Outline Series, McGraw-Hill Publishing Company Ltd.

45. Van Horne, J.C., 1970. New Listings and their Price Behaviour. Journal of Finance, 25 (4), pp. 783-794. 